cuttings root best. "The time of taking cuttings should be governed by the condition of the material rather than by the calendar." Various methods of application of synthetic hormone substances are described and, although these still give varying results, they represent by far the greatest single advance in technique. The effects of temperature, moisture and light form an interrelated complex, which should be determined for each species. Wound stimulation can increase rooting response; leaves are generally necessary, but flowers are a hindrance to regeneration.

Rooting media must be well aerated, but must also hold sufficient moisture; peat is considered to provide rooting stimulants, possibly of hormone nature. Some stem cuttings root better after an initial period of inversion, while some root cuttings regenerate better if the proximal end is above the compost. The presence of nitrogen hinders the rooting of normal plants, but nitrogen-starved growth may occasionally be stimulated to root by treatment with suitable nutrient solutions. Layering and marcotting (aerial layering) appear to depend for their full success upon some form of constriction or ringing which presumably increases the carbohydrate in the parts which are to root. Mr. Garner finally discusses the application of principles revealed by his survey to the practices of propagating fruit trees in use at the East Malling Research Station. Many orchards and nurseries are at present in bad condition because of the War, and Mr. Garner's publication has the objective aim of demonstrating the best methods for their restoration when peace returns.

\section{GROWTH OF CEREAL EMBRYOS}

GINCE the pericarp in a cereal such as barley is $N$ semi-permeable, during the first period of germination the embryo is exposed to a low level of water and oxygen availability $(0 \cdot 1$ atm. $)$ and a relatively high carbon dioxide concentration (0.1 atm.) (R. Brown, Ann. Bot., N.S., 93 and 275 ; 1943). In contrast, when excised embryos are being cultured, as in attempts to elucidate some of the problems of vernalization and kindred phenomena, the young plants are being started under conditions of high water and oxygen availability. Whether grown on water or culture solutions, such isolated embryos always show an immediate drop in dry weight, followed by a slower loss over at least the first twelve hours, suggesting a leaching effect followed by a rather higher rate of respiration than in the embryos of intact grains.

The change-over from a dormant embryo with dense non-vacuolate cells to a seedling in a fully active state seems to occupy about the first seventytwo hours, since after that time the water content remains constant. Although the food reserves in the endosperm are not available to the young plant during the first twenty-four hours of germination, excision within the first twelve hours of germination affects the linear and dry-weight growth, suggesting either that some substance is being absorbed (a hormone?) or that the internal carbon dioxide concentration has a stimulating effect, either directly or by altering the acidity of the environment. When the carbon dioxide concentration is high, as in an intact grain, a low level of water-availability stimulates the linear and dry-weight growth of the embryo, either when attached or when growing on a nutritive medium. On the other hand, linear and dry-weight growth do not appear to be influenced by changes in oxygen concentration provided it is above about 15 per cent.

"Each of the factors considered above tends to be at a level inside the seed which, relative to the incident level of the same factor outside the seed, stimulates the subsequent growth of the seedling"; and there is probably "a high degree of instability in the metabolic pattern of the embryo . . subject to modification according to the nature of the environment in which early development occurs".

\section{FORTHCOMING EVENTS}

(Meeting marked with an asterisk: * is open to the public)

\section{Saturday, November 25}

AsSOCIATION For SCIENTIFIC PHotography (joint meeting with the Sctentific and Technical group of the Royal Photographic SocIETX) (at 16 Princes Gate, South Kensington, London, S.W.7), at 3 p.m.-Mr. G. Parr: "The Electron Microscope": Dr. E. M. Crook, Miss F. M. L. Sheffeld and Mr. L. V. Chilton: "Photographic "Electron Micrography of Textiles".

\section{Monday, November 27}

Royal Society of ARTs (at John Adam Street, Adelphi, London, ROYAL SOCIETY OF ARTS (at John Adam "Milk"et, Ad "The Hormonal W.C.2), at 1.45 p.m.--Dr. S. J. Folley: "D.
Control of Lactation" (Cantor Lecture).

ROXAL GEOGRAPHICAL SOCIETY (at Kensington Gore, South Kensington, London, S.W.7), at 5 p.m.-Mr. C..Hope Gill: "The Hadhramaut" (Kodachrome Film).

BRITISH INSTITUTION OF RADTO ENGINEERS (LONDON SECTION) (at the Institution of Structural Engineers, 11 Upper Belgrave Street, hondon, S.W.1), at $6 \mathrm{p}, \mathrm{m}$ - Mr. E. R. Friedlander: "Magnetic Dust Cores".

INSTITUTYON OF ELECTRICAL ENGINEERS (LONDON STUDENTS' SECrIoN) (at Savoy Place, Victoria Embankment, London, W.C.2), at 7 p.m.-Mr. W. A. Hatch: "Some Hydro-Electric Possibilities and Achievements".

IRON AND STEEL INSTITUTE (joint meeting with the SHEFFIELD BRANCH OF THE INSTITUTE OF BRITISH FOUNDRYMEN) (at the Roya Victoria Hotel, Sheffield), at 7 p.m.-Mr. B. Gray: "The Side Feeding of Steel Castings - a Note on the Influence of the Mechanism of Freezing".

\section{Tuesday, November 28}

British Psychological Societry (Industrial Section) (at the National Institute of Industrial Psychology, Aldwych "House, Aldwych, London, W.C.2), at 12.45 p.m. -Prof. E. A. Bott: "Some Problems of Selection and 'Training in War and in Peace" (followed by Questions

ROX AL ANTHROPOLOGICAL INSTITUTE (at the Royal Society, Burlington House, Piccadilly, London, W.1), at 1.30 p.m.-Prof. V. Gordon Childe: "Archæological Ages as Technological Stages" (Huxley Memorial Lecture).

Institotion of BrTtish Agrtcultural Engineers (at the Institution of Electrical Engineers, Savoy Place, Victoria Embankment, London, W.C.2), at 2 p.m.-Mr. C. Culpin: "Machinery for Crop Cultivation".

CHADWICK LECTURE (at the Sir Edward Meverstein Lecture Theatre, Westminster Hospital Medical School, 17 Horseferry Road, WestWestminster Hospital Medical school, 17 Horserery Hoad, Wrincker minster, London, S.W.1), at 2.30 p.m.-Mr. J. A. H. Brincker "Research in all its Various Aspects Essential corm Morris Memorial Health and ${ }^{*}$

RoYal Institurtion (at 21 Albemarle Street, Piccadilly, London, WOY 15.15 p. Diseases", (ii) "The Properties of Purified Plant Viruses".

ROYAL STATISTICAL SOciety (at the Royal Society of Arts, John Adam Street, Adelphi, London, W.C.2), at 5.15 p.m.-Sir William Elderton: "C'ricket Scores and Some Skew Correlation Distributions (An Arithmetical Study)": Mr. George H. Wood: "Cricket Scores and Geometrical Progression".

Institute of Petrolkum (at 26 Portland Place, London, W.1), at 5.30 p.m. - Reception to the Visiting Indian Scientists, when addresses will be

Institution of Civit ENGineers (at Great George Street, Westminster, London, S.W.1), at 5.30 p.m.-Mr. A. Shaw Maclaren: "The Design of Land Airports for Medium and Long Distance Civil Air Transport",

NORTH-EAST COAST INSTITUTION OF ENGINEERS AND SHIPBCILDERS, (in the Lecture Theatre of the Mining Institute, Newcastle-upon-Tyne) at $6 \mathrm{pm}-\mathrm{Mr}$. E. Leslie Champness: "University Education in Shipbuilding and Naval Architecture".

SheFrield Metallurgicai Association (at 198 West Street, SHEFTIELD METALLURGICAI ASSOCIATION (at 198 West Street Banded Structures in Centrifugal Casting". 